\title{
GLACIER FLUCTUATIONS AND CLIMATE IN THE CORDILLERA BLANCA, PERU
}

\author{
by \\ Georg Kaser \\ (Geographical Institute, University of Innsbruck, Innrain 52, A-6020 Innsbruck, Austria) \\ and \\ Alcides Ames and Marino Zamora \\ (Hidrandina S.A., Glaciologia e Hidrologia, Jr. 28 de Julio 857, Huaraz (Ancash), Peru)
}

\section{ABSTRACT}

With a total of $723 \mathrm{~km}^{2}$ of glaciers (1970) the Cordillera Blanca includes the largest glacier-covered area in the tropics. The climate is characterized by relatively large daily and small seasonal temperature variations as well as by a distinct succession between a dry (May-September) and a wet season (October-April). Since the early 1970s an ablation stake network has been installed on the tongues of the glaciers Uruashraju and Yanamarey. The determination of the equilibrium-line altitude at each end of a wet season was possible, showing a fair correlation with temperature, but not with the precipitation records of the nearby climatological station Querococha. Mean ablation rates at the lowest parts of the glacier tongues are markedly higher during the wet season than during the dry season. Reasons are presumably to be found in the seasonal variation of cloudiness and air moisture rates. Terminus variations of four glaciers in the Cordillera Blanca have been monitored since the early seventies, earlier positions are reconstructed back to 1948 by vertical air photographs. For the glaciers Uruashraju and.Yanamarey the terminus positions of 1939 are known from an early map. The general retreat of glaciers in the Cordillera Blanca during the last five decades correlates with the global attitude of glaciers and especially with the attitude of glaciers in other tropical areas. Decreased recession rates with minor advances (1974-79 and 1985-86) are accompanied by lower annual temperatures and preceded and accompanied by years with relatively high annual precipitation sums.

\section{INTRODUCTION}

With 722 glaciers covering a total area of $723 \mathrm{~km}^{2}$ (Ames and others, 1988; based on vertical infrared NASA air photographs from 1970) the Cordillera Blanca $\left(8^{\circ} 30^{\prime}-\right.$ $10^{\circ} \mathrm{S}$ and $\left.77^{\circ} 50^{\prime}-77^{\circ} 10^{\prime} \mathrm{W}\right)$ includes the largest glaciercovered area in the tropics (Fig. 1). The earliest detailed glaciological information about the Cordillera Blanca is based on the research and resulting topographical maps of $\mathrm{H}$. Kinzl who worked from 1932 in a number of scientific expeditions to the area (Borchers, 1935; Kinzl, 1942, 1949, 1964). At least since then the glaciers have continuously receded. In the present paper the authors try to analyse glaciological and climatological data and to explain the recorded glacier retreat.

The climate in the Cordillera Blanca is characterized by relatively large daily and small seasonal temperature variations as well as by a distinct succession between dry (May-September) and wet seasons (October-April) (Fig. 2). Thus the mass accumulation on the glaciers occurs almost entirely during the wet season. Observations show that occasional snow cover on the tongues melts within a few

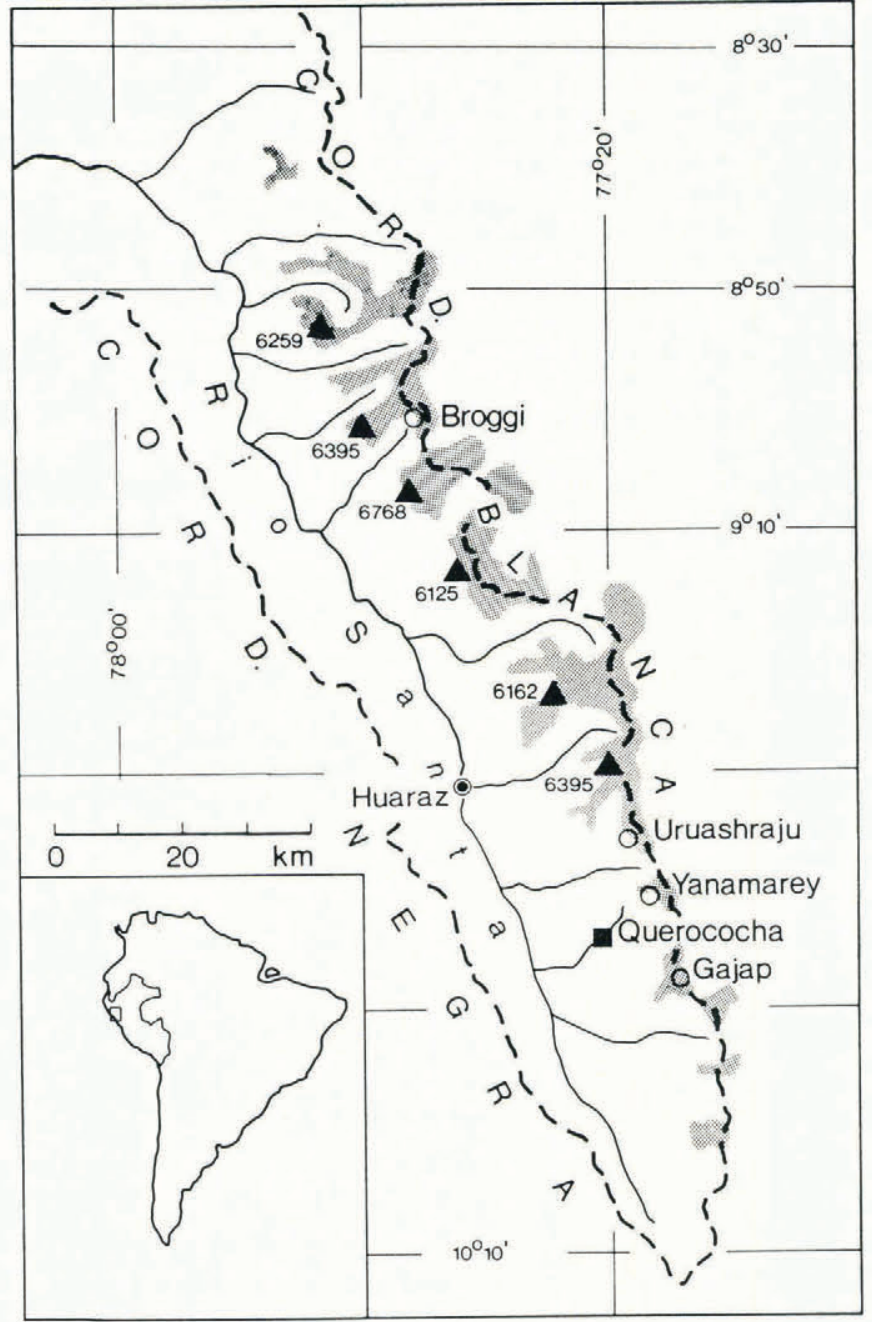

Fig. 1. The Cordillera Blanca and watershed of the Rio Santa catchment. Triangles indicate the chain of the highest peaks. The positions of Broggi, Uruashraju, Yanamarey and Gajap glaciers and the Querococha climatological station are shown. Glaciers are represented by shaded areas.

days. Thus the mass accumulation occurs almost entirely in the upper part of the glaciers.

Two peculiarities affect the seasonal and topographical distribution of precipitation and thus also the glacial regime in the Cordillera Blanca: 


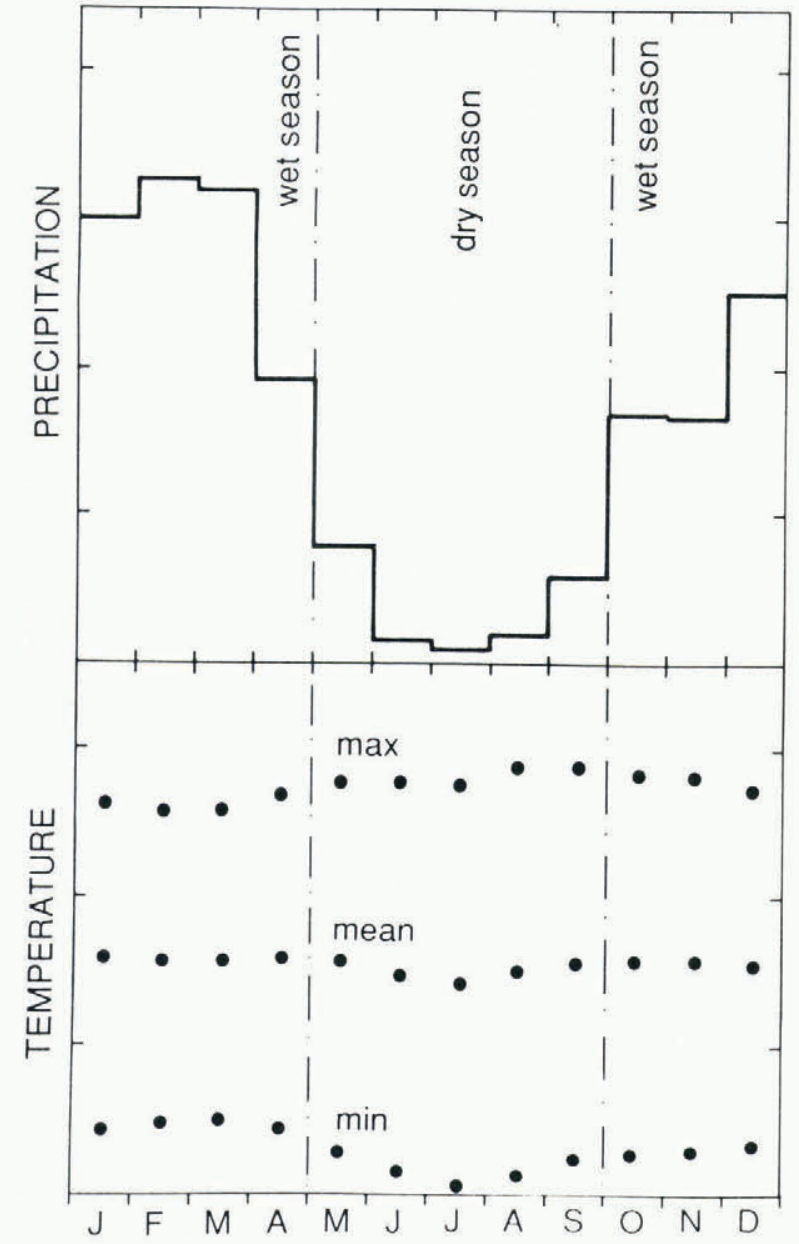

$\mathrm{mm}$

Fig. 2. Mean monthly precipitation (1954-1987) and maximum mean and minimum temperatures (monthly means 1965-1987) at Querococha (3955 m).

(a) The oscillation of the cloud and precipitation belt of the Intertropical Convergence Zone (ITCZ) causes the seasonal distribution of precipitation.

(b) Due to the geological structure of the Cordillera Blanca the watershed of the Rio Santa catchment area lies a few kilometers east of the highest peaks (Fig. 1). The moist air masses brought by the ITCZ from the southeast overlap the watershed and therefore cause ample precipitation also in the high altitude, leeward catchment areas and glaciers of the Cordillera Blanca (Fliri, 1968).

Figures 3 and 4 show these processes and their effects schematically.

\section{MASS BALANCE RECORDS}

\section{Glaciers Uruashraju and Yanamarey}

Since the early seventies an ablation stake network has been installed on Uruashraju and Yanamarey glaciers (Fig. 1). These are situated in the southern part of Cordillera Blanca. Both glaciers face southeast. Uruashraju covers an area of approximately $2.1 \mathrm{~km}^{2}$ between 4600 and $5700 \mathrm{~m}$ a.s.1., Yanamarey approximately $1.25 \mathrm{~km}^{2}$ between 4600 and $5200 \mathrm{~m}$. Since 1975 the tongue has been calving into a small moraine-dammed lake. From 1980/81 the stakes were measured at the ends of both the wet and the dry season, yielding the seasonal net mass balances for these points. Following the definition of the mass balance year as extending from one entire glacier mass minimum to the next, the end of the dry season is the end of the mass balance year. For the years $1977 / 78$ to $1979 / 80$ it was possible to reconstruct the net balance amounts for the respective wet seasons.

To obtain a smoothed distribution of specific mass balance $\mathrm{b}$ with altitude $\mathrm{z}$, mean values at $50 \mathrm{~m}$ steps in elevation were calculated. Three to 12 single values were

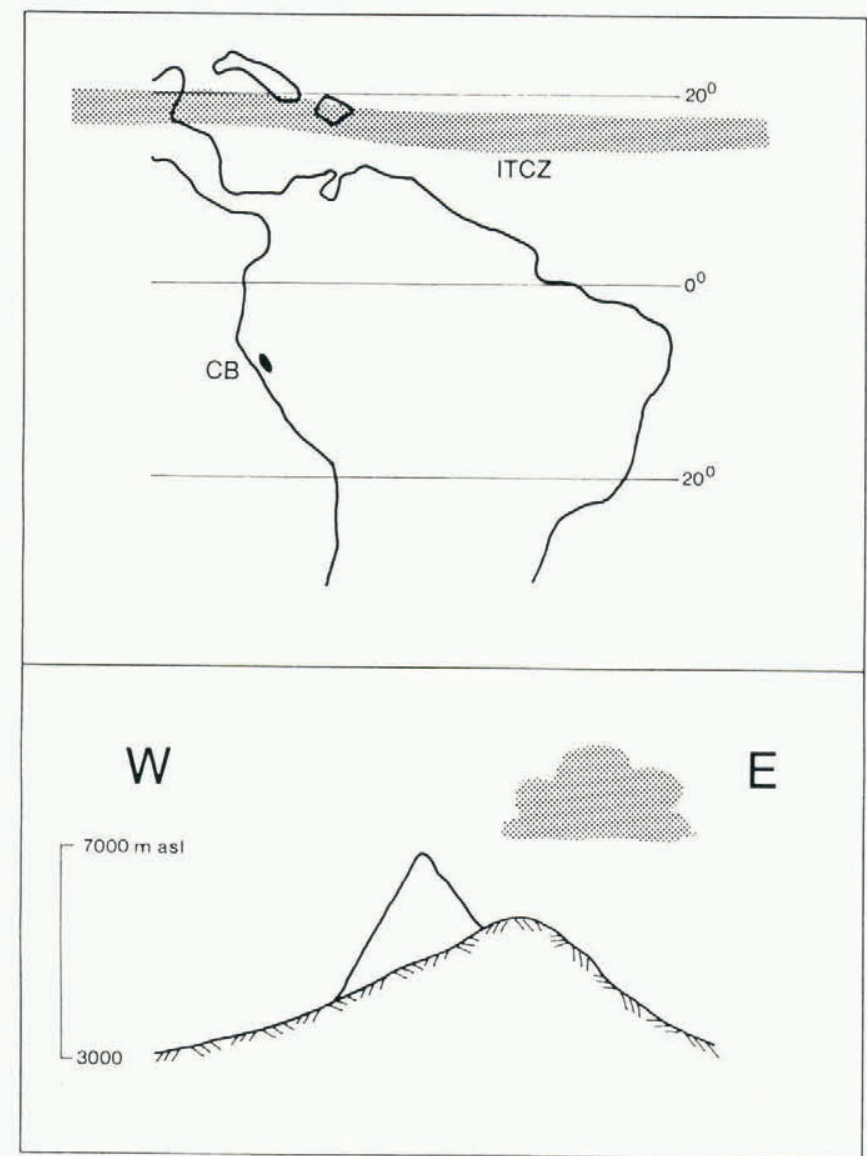

Fig. 3. Idealized position of the Intertropical Convergence Zone (ITCZ) above South America in July and August (after Graf, 1986) and schematic illustration of the dry season weather conditions in the Cordillera Blanca (CB).

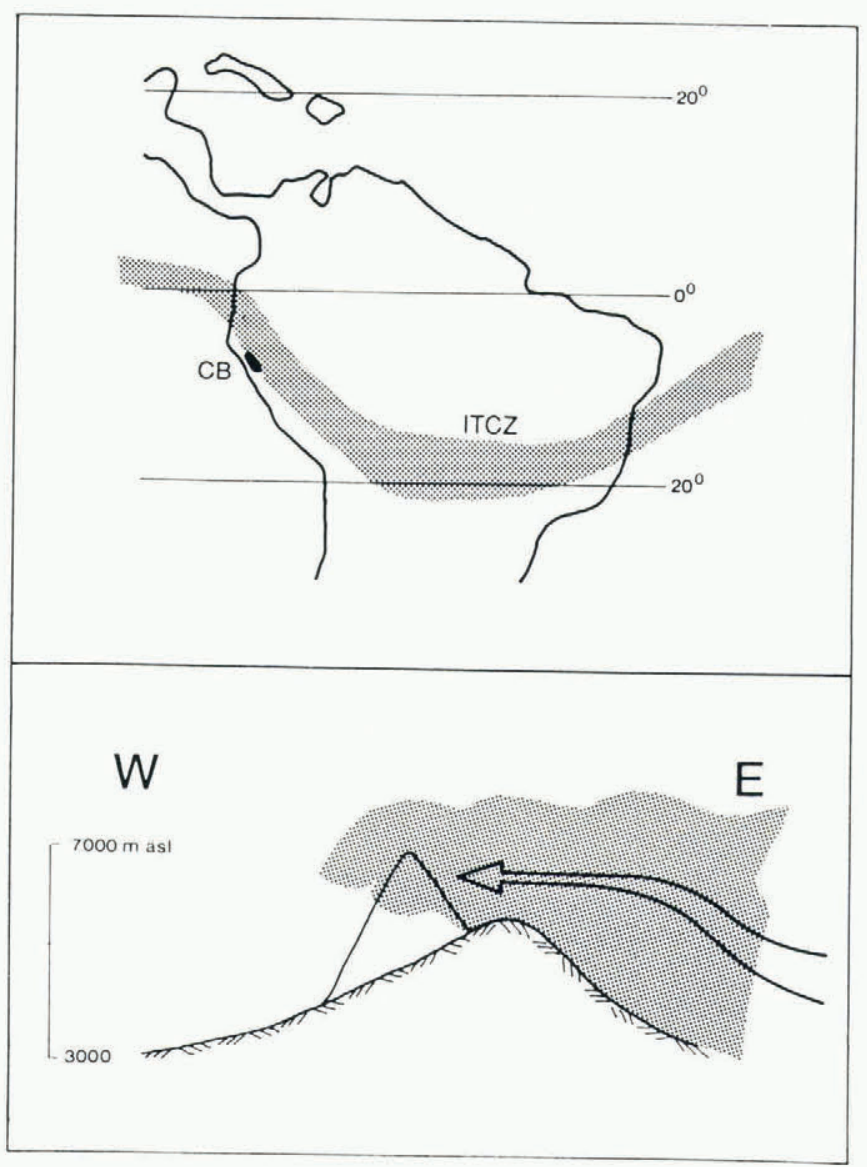

Fig. 4. Idealized position of the Intertropical Convergence Zone (ITCZ) above South America from November to April (after Graf, 1986) and schematic illustration of the wet season weather conditions in the Cordillera Blanca (CB). 


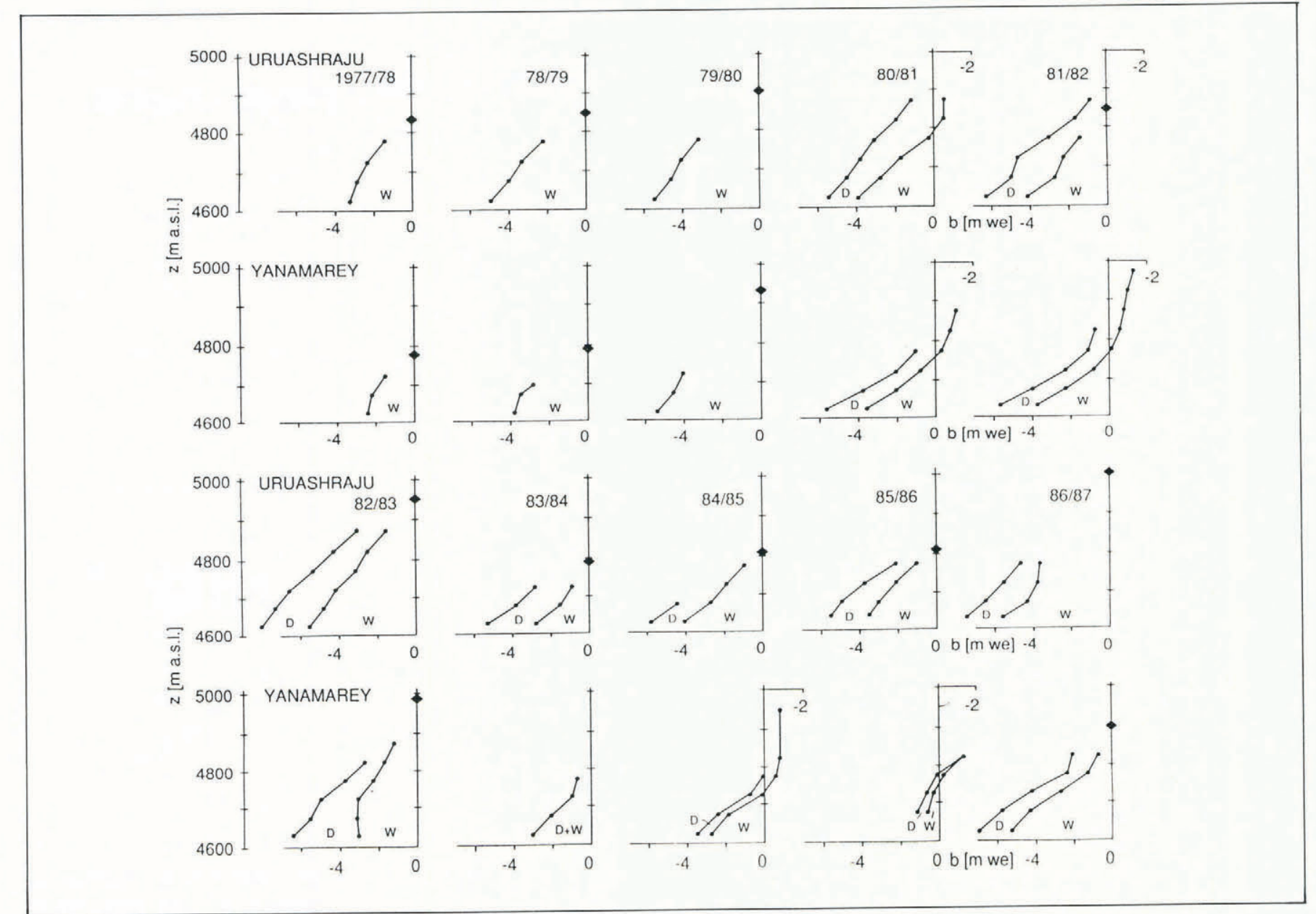

Fig. 5. Variations in specific mass balance $b$ with altitude $z$ for the tongues of Uruashraju and Yanamarey glaciers. For most cases it was possible to subdivide the annual specific mass balance $(W+D)$ into the seasonal balances of the wet (W) and the dry (D) season. Further explanations are given in the text.

used for each zone. The results in Figure 5 show that ablation occurs on the glacier tongues throughout the year.

Equilibrium-line altitude at the end of the wet season $\left(\operatorname{ELA}_{\mathbf{w}}\right)$

The uppermost ablation stakes in a number of years were situated in the accumulation zone of the glaciers permitting determination of the $\operatorname{ELA}_{\mathbf{w}}$. For other years ELA $_{w}$ values were obtained by graphical extrapolation. These extrapolations are rough for $1979 / 80$ on both Uruashraju and Yanamarey, for $1982 / 83$ and $1983 / 84$ on Yanamarey and for $1986 / 87$ on Uruashraju) (Fig. 5).

$E_{\mathrm{w} A}$ values are plotted for both glaciers in Figure 6, along with mean temperatures and precipitation sums for the respective wet seasons. Climatological data were recorded at station Querococha, situated at $3955 \mathrm{~m}$ a.s. $1.10 \mathrm{~km}$ from the Yanamarey glacier (Fig. 1). It is obvious that $\mathrm{ELA}_{\mathrm{w}}$ correlates with temperatures, but not with precipitation. Statistical analysis confirms a fairly high correlation coefficient $r$ between a mean ELA $_{w}$ of both glaciers with the maximum temperatures $\left(\mathrm{ELA}_{\mathrm{w}}: \mathrm{t}_{\max , \mathrm{w}} ; r=0.69\right.$ ), the mean temperatures (ELA ${ }_{w}: t_{\text {mean, } w} ; r=0.79$ and the minimum temperatures $\left(E L A_{w}: t_{\min , w} ; r=0.71\right)$ whereas the correlation coefficient with the wet season precipitation sums is $r=-0.09$.

Highest accumulation occurs in the wet season but ablation is also large; the height of the equilibrium line is primarily dependent on the altitude of transition from snow to rain. Lack of records make it impossible to establish what happens in areas of accumulation, or to establish the entire mass balance of both glaciers.

\section{Ablation during wet and dry seasons}

A reconstruction of the equilibrium line at the end of the dry season and thus at the end of the entire mass balance year is, in the view of the authors, hardly possible due to absence of enough information. But it is possible to compare the specific mass balance of the wet season with the ones of the dry season for the lowest areas of both tongues. Table I shows data for altitudes between 4600 and $4650 \mathrm{~m}$ a.s.l. for both the glaciers.

Mean ablation rates on the glacier tongues are roughly a third higher in the wet season than in the dry. This fact leads to assumptions with regard to heat balance which have to remain speculative due to lack of energy balance investigations.

During the wet season, denser cloud cover and a higher air moisture rate might be the reasons for the fact that the energy flux due to longwave radiation and sensible heat flux play an important role. During the dry season this energy amount, which is available for melting, is smaller for the following reasons:

- Air masses are drier and cloud cover is less than in the wet season. This leads to higher amounts of nocturnal outgoing longwave radiation and therefore to lower temperatures of the ice surface (see minimum temperatures in Figure 2), which in the course of the day have to be heated up to melting point.

- The drier air causes higher evaporation rates but they equal only one seventh of the mass loss, which could melt in other processes requiring the same amount of energy (Kaser, 1983, 1986).

- High evaporation as shown by Hastenrath (1978) at the Quelccaya Ice Cap in southern Peru together with the shortwave solar radiation causes heavy differential ablation (even "nieve penitentes") and so a rougher, more porous ice surface. Such a ice surface seems to look whiter and thus points to a higher albedo, which reduces the energy absorbed. 


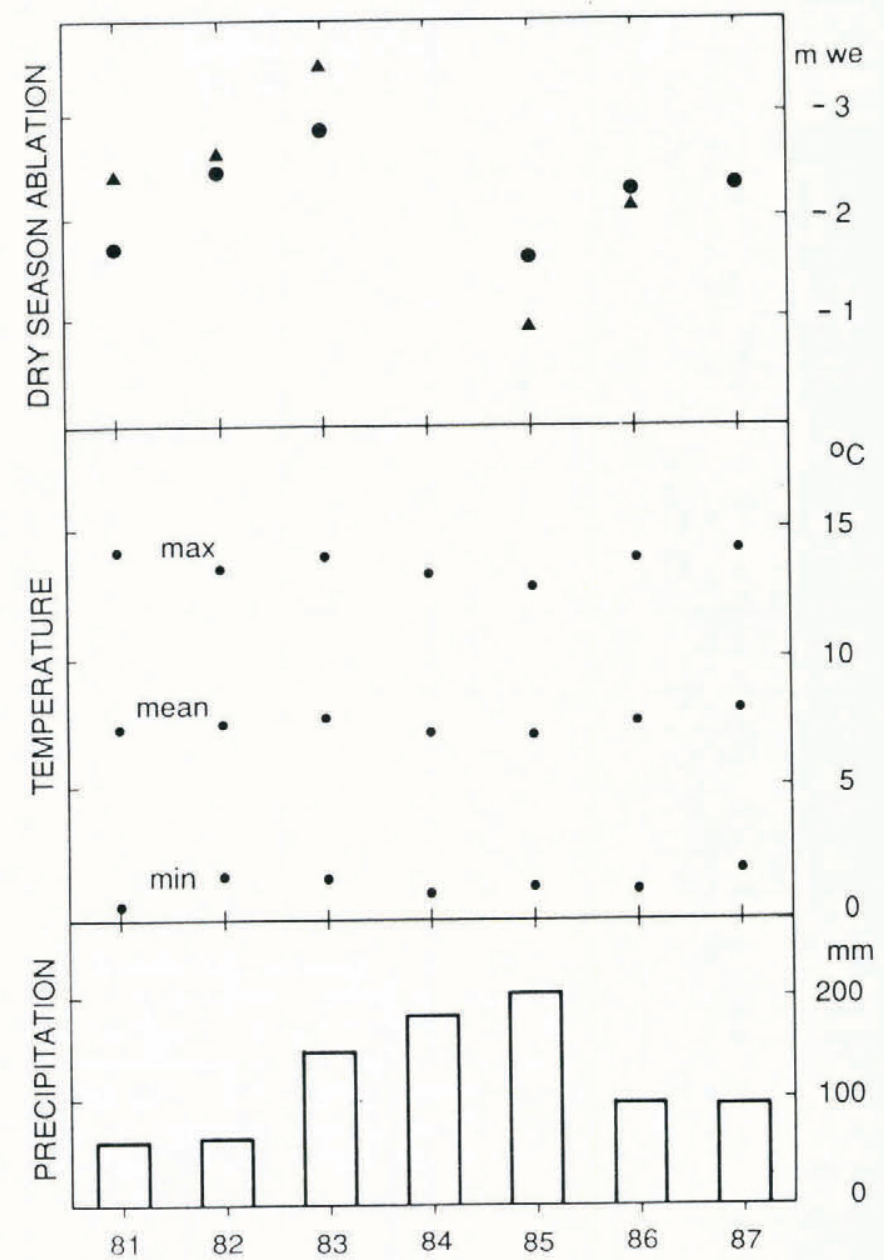

Fig. 7. Dry season mean net ablation values for the $4600-4650 \mathrm{~m}$ elevation steps of Uruashraju (circles) and Yanamarey (triangles), and mean temperatures and precipitation sums for the respective dry seasons, recorded at Querococha.

and others, 1985), but correlate with the general advances in the Alps and the North American cordilleras (Patzelt, 1987).

While the strong retreat of Lewis Glacier on Mount Kenya is thought to be caused by relatively low precipitation, variations on the Cordillera Blanca glaciers correlate with both precipitation and air temperatures. Variations in air temperatures in the tropics are in principle not dependent on the dynamics of different air masses but, almost without exception, are controlled by local energy balance. Both seasonal and long-term variations of energy balance are caused principally by variation of atmospheric moisture and cloudiness, which in the tropics are linked to intensity and pattern of the ITCZ.

Due to the lack of accumulation records, knowledge of mass balance of glaciers in the Cordillera Blanca has to be limited to the ablation zone. The generally steep and rugged accumulation areas are of ten threatened by ice avalanches and therefore usually inaccessible. The glacial regime in the Cordillera Blanca is generally indicated by the occurrence of ablation during the entire year and of accumulation almost exclusively during the wet season and in the firn area. Ablation rates are markedly higher during the wet season.

Analysis of the available glaciological and climatological data permit a number of conclusions. Detailed knowledge of the energy budget and questions relating to mass accumulation have to remain open.

\section{REFERENCES}

Ames, A., and seven others. 1988. Inventario de glaciares del Peru. Primera parte. Huaraz, Hidrandina S.A. (Unidad de Glaciologia e Hydrologia 171.)

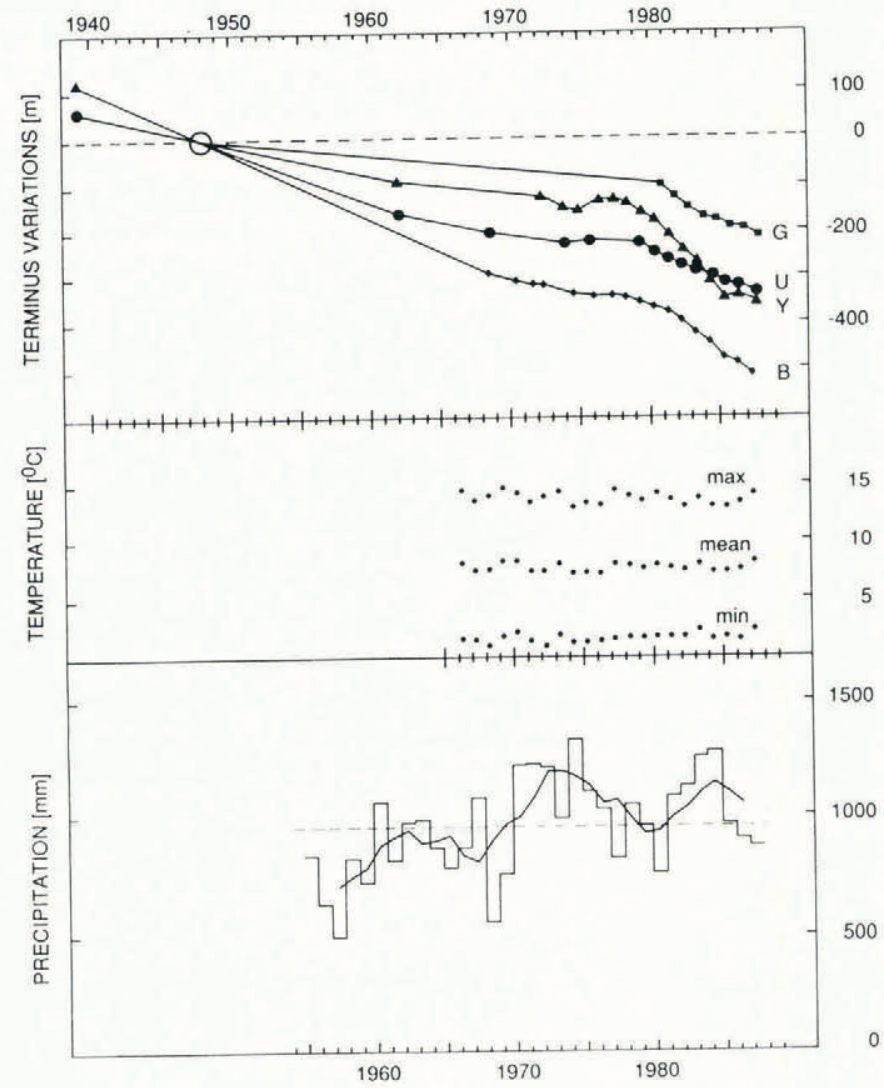

Fig. 8. Terminus variations of Gajap (G), Uruashraju (U), Yanamarey (Y) and Broggi (B) glaciers, starting from a common reference point in 1948. For Uruashraju and Yanamarey the terminus positions of 1939 were reconstructed. In the middle, annual mean temperatures are plotted, while the lowest graph shows the annual amounts of precipitation with an overlying five-year running mean curve. The broken line indicates the long-term average of precipitation. Climatological data were recorded at Querococha.

Borchers, P. 1935. Die Weisse Kordillere. Berlin, Verlag Scherl.

Fliri, F. 1968. Beiträge zur Hydrologie und Glaziologie der Cordillera Blanca (Peru). Veröff. Univ. Innsbruck, Alpenkund. Stud., 1, 25-52.

Graf, K. 1986. Klima und Vegetationsgeographie der Anden. Grundzüge Südamerikas und pollenanalytische Spezialuntersuchungen Boliviens. Zürich, Universität Zürich. (Physische Geographie.)

Hastenrath, S. 1978. Heat-budget measurements on the Quelccaya ice cap, Peruvian Andes. J. Glaciol., 20(82), 85-97.

Hastenrath, S. 1984. The glaciers of equatorial East Africa. Dordrecht, etc., D. Reidel Publishing Company.

Hidrandina S.A. Unpublished. Glaciological and climatological data.

Kaser, G. 1983. Über die Verdunstung auf dem Hintereisferner. Z. Gletscherkd. Glazialgeol., 19(2), 1983, 149-162.

Kaser, G. 1986. The role of evaporation from snow and ice in the mass balance of a glacier. Mater. Glyatsiol. Issled. $57,185-188$

Kinzl, H. 1942. Gletscherkundliche Begleitworte zur Karte der Cordillera Blanca (Peru). Z. Gletscherkd., 28(1/2), 1-19.

Kinzl, H. 1949. Die Vergletscherung in der Südhälfte der Cordillera Blanca (Peru). Z. Gletscherkd., 1(1), 1-28.

Kinzl, H. 1964. Begleitwort zur Karte 1:100000 der Cordillera Blanca (Peru) Südteil. Wiss. Alpenvereinsh. 1.

Patzelt, G. 1987. Die gegenwärtigen Veränderungen an Gebirgsgletschern der Erde. Frankfurter Beitr. Didakt. Geogr., 10, 41-50.

Patzelt, G., E. Schneider, and G. Moser. 1985. Der Lewis-Gletscher, Mount Kenya. Begleitworte zur Gletscherkarte 1983. Z. Gletscherkd. Glazialgeol., 20 1984, 177-195. 